\title{
PHOTOGRAMMETRY USING VIRTUAL RESTORATION OF WALL-PAINTINGS OF THE ROCK-HEWN CHURCHES IN THE GÖREME VALLEY, CAPPADOCIA AND ITS VALUE FOR THE MUSEUM'S CONTENTS
}

\author{
R. Higuchi ${ }^{1, *}$, H. Sugawara ${ }^{2}$, M. E. Gülyaz ${ }^{3}$ \\ ${ }^{1}$ Center for Cultural Resource Studies, Kanazawa University, Japan - higuchi.r.7496@gmail.com \\ ${ }^{2}$ Faculty of Letters, Kanazawa University, Japan, - h.suga0616@staff.kanazawa-u.ac.jp \\ ${ }^{3}$ Nevşehir Museum, Turkey - muratgulyaz@gmail.com
}

Commission II, WG II/8

KEY WORDS: Rock-hewn churches in Cappadocia, Wall painting, Photogrammetry, Virtual Restoration, Museum Contents

\begin{abstract}
:
Göreme Valley located in the center of Cappadocia, Turkey is famous for its spectacular landscape characterized by erosion. There are more than one hundred rock-hewn churches in Göreme Valley and some of them have distinct wall-paintings in the Byzantine style. Although a significant place for Byzantine art many of the churches here are at risk of collapse due to erosion. Furthermore there is no comprehensive documentation of the churches concerning both the wall-paintings and their three-dimensional shapes This paper aims: 1) to present two kinds of virtual restoration using 3D-modeling by photogrammetry, virtual toning and virtual restoration, based on Göreme Valley's special context, in which many churches were painted by the same painter/workshop; 2) to discuss the value of the use of 3D-modeled materials as a museum exhibition.
\end{abstract}

\section{INTRODUCTION}

Göreme National Park and the Rock Sites of Cappadocia, registered UNESCO's World Heritage list in 1985, is located in Nevşehir Province, $280 \mathrm{~km}$ southeast of Ankara, capital of Turkey (Figure 1). It is in this spectacular landscape, wherein rock-hewn sanctuaries provide unique evidence of Byzantine art from the post-iconoclastic period, especially during the 9th and 10th centuries (criteria for selection (i)). The most significant part of Byzantine art in Cappadocia are the paintings on interior walls of churches. While many wall-paintings were damaged as the churches were abandoned for extended periods of time, surviving examples allow us to imagine the decorated interior of the churches, which were covered with these paintings at that time. From this, we can gain a significant amount of information about such paintings from the 9th to 10th century when few surviving articles remain.

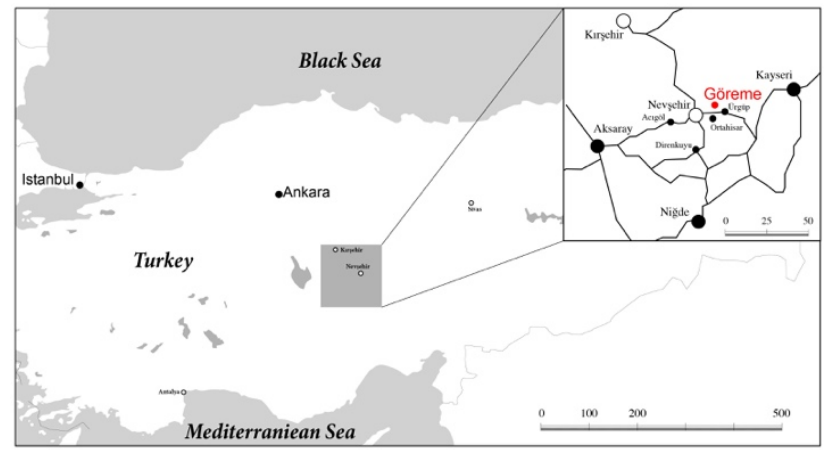

Figure 1. Map of Göreme, Cappadocia and Turkey

The spectacular landscape of Cappadocia depends on the fact that most of the rock here is tuff which is easily eroded. In other words, the rocks from which the churches were hollowed out of are gradually disappearing (Erguler, 2009). A prominent example of the deterioration and subsequent collapse due to erosion is found in the rock-hewn churches of the Göreme Valley, specifically of the Göreme Open-Air Museum and of the area surrounding it. The valley marks the center of Cappadocia and has period examples of more than 100 churches from the end of the 9th century to the 11th century (Jerphanion, 1925-1942; JolivetLévy, 1991; Jolivet-Lévy, 2015) including famous masterpieces such as Tolalı Kilise (10th century) or Karanlik Kilise (11th century). However, extended abandonment of the churches also brought along artificial damages. Wall paintings in the churches have many scars and damage, even extending to graffiti. Therefore, with a few exceptions like the churches of the OpenAir Museum which have been restored in order to demonstrate the beauty of these pieces to the public, the overall importance of the preservation of the Cappadocian Churches as a whole only came to be realized towards the beginning of the 20th century after the publication of G. de Jerphanion's (1925-42) work on the subject. In addition, factors such as the rapidly increasing number of tourists also affect the preservation effort. Because of this, Karanlık Kilise, the highlight of the museum, was closed to the public in February 2019.

Thus, the importance of preserving the environment surrounding the churches became a priority. Nevertheless, the documentation of Cappadocian churches is fragmented and unsystematic as there is an uncountable number of churches in the area. While many art historians like Jerphanion (1925-42), Thierry (1973; 1996), Restle (1969) and Jolivet-Lévy (1991; 2015), documented the wall-paintings, they tended to overlook the three-dimensional characteristics of the churches. Although recent development of digital documentation shed a spotlight (Cariceci and Inglese, 2014; Colonnese et al., 2016), these studies are, for the most part, using laser scanners or drone-based aerial photography focused on the monuments themselves or structures of the area. However, documentation of both the three-dimensional shape and positional relationships of each icon on the surface must be important as the allocation and positional relationships of each icon also come into having further meaning (Masuda, 2014).

From the above, we started the documentation of the churches to make 3D-models using photogrammetry in 2015. The aim of this article is to show the methods of virtual restoration and to discuss 
the value of its use in museum exhibitions. The churches in Göreme Valley, which are well suited to stylistic analysis as many churches are concentrated in the same area and some of whose painters/workshops pointed out in the previous studies, are good examples to work with. Moreover, although many scholars understand the comparison of the images of wall paintings by anonymous painter/ workshop enables to restore the damaged wall paintings, restoring the wall paintings from the remained images, with copying and modifying, is not so often and especially it is truly rare case to use such restoring image as museum contents as far as the authors know. The photogrammetry application we used is Agisoft PhotoScan and our instruments for imaging were a Nikon DF (CMOS sensor, $36.0 \times 23.9 \mathrm{~mm} ; 16.2 \mathrm{MP})$ and AF-S Nikkor lens $(14-24 \mathrm{~mm}$ $\mathrm{f} / 2.8 \mathrm{G} \mathrm{ED})$.

\section{VIRTUAL RESTORATION OF THE WALL- PAINTINGS USING 3D-MODELING}

\subsection{Virtual Toning}

The first method of virtual restoration is virtual toning, i.e. to fix colors of the small scars or detachments of paintings. We made the 3D-modeling of the Agios Eustathios church (the first half of 10th century), located outside of the Open-Air Museum, by Agisoft PhotoScan with 120 pieces of photos (Figure 2). Then we acquired four pieces of textures (8000-pixel x 8000-pixel) of 3Dmodeling to maintain a high-resolution (Figure 3). As Figure 4 (seen in the red box of figure 3 ) shows, there are several kinds of damage found on the wall-paintings. Among these, we can assume the colors of the small lost part based on the composition of the icons. Figure 5 is an example to tone the color using 'Eyedropper Tool' of Photoshop. Although this is just fixing the smaller lost parts of the icon, the painting itself becomes clearly distinct and makes the viewers imagine the original condition easily even for non-professionals.

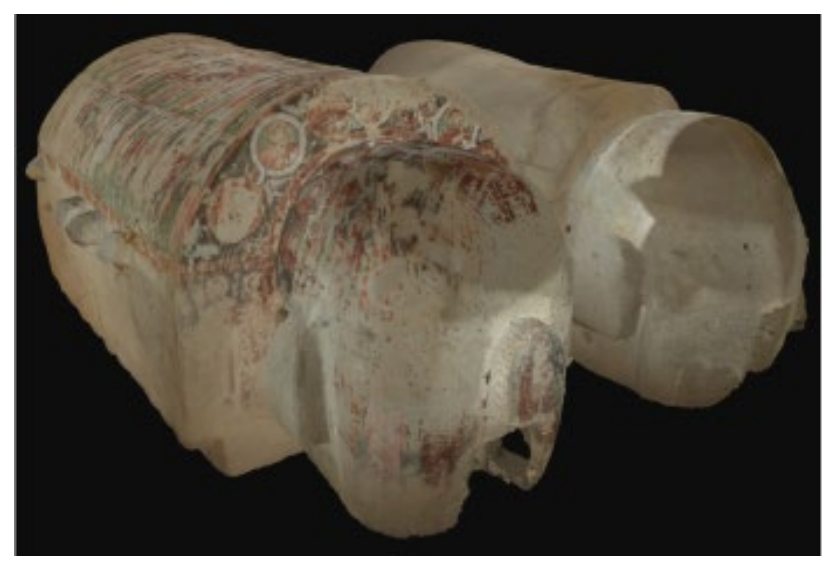

Figure 2. 3D-Modeling of Agios Eustathios Church
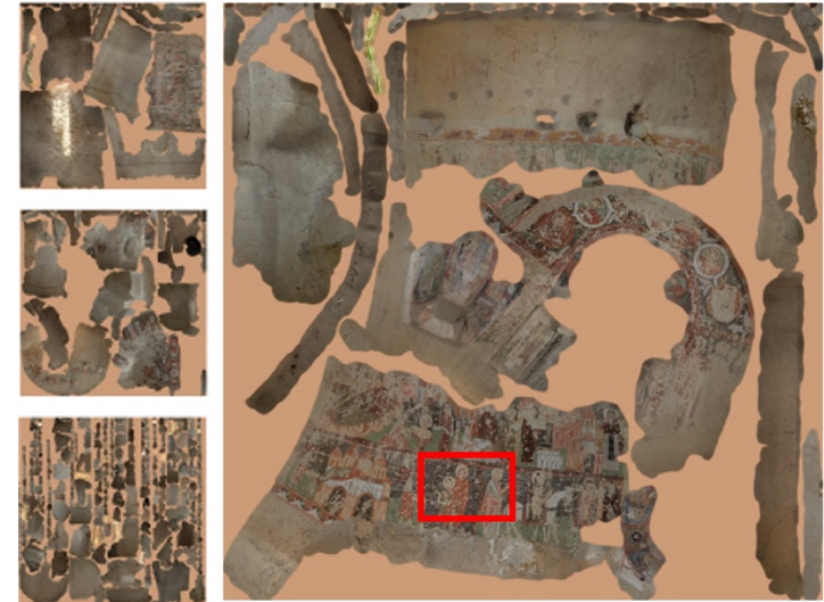

Figure 3. Four textures of wall-paintings of Agios Eustathios

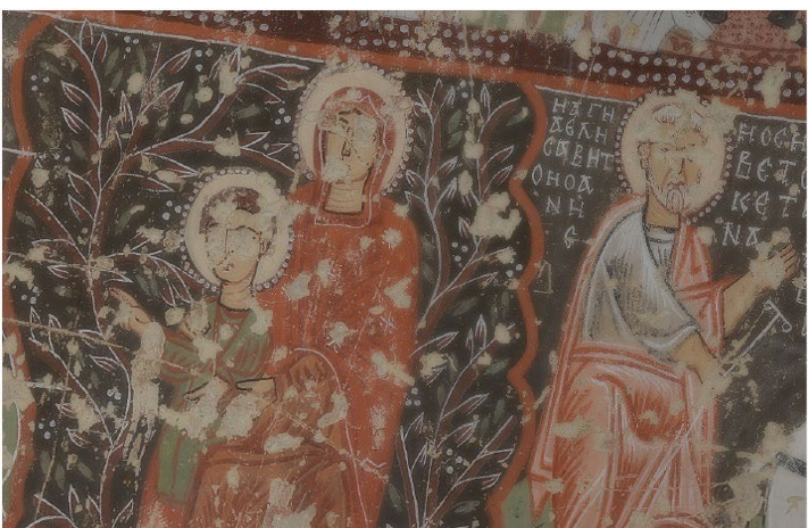

Figure 4. The current condition of the wall-Painting

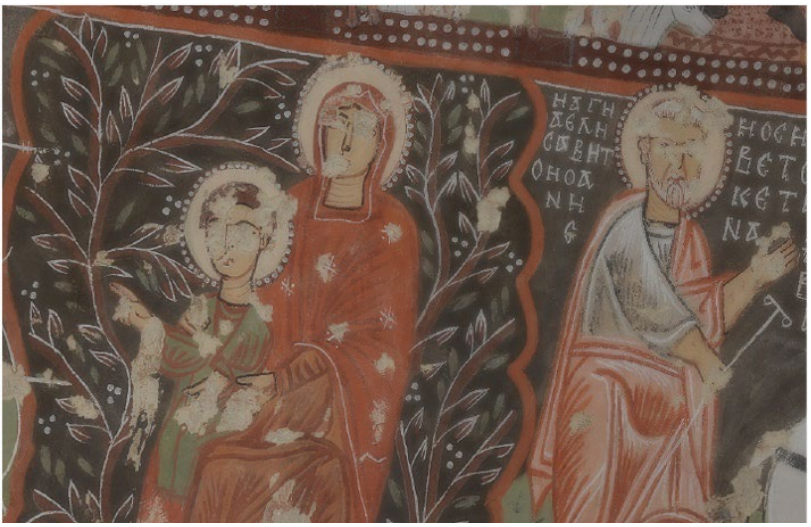

Figure 5. Wall-painting after virtual toning

However, depicting brush strokes or gradations of the colors, or painting habits to the $3 \mathrm{D}$-modeling is very difficult technically as the toning is filling the color using the existing part. Therefore, while it is questionable whether it is realistic as it may require extremely high-performance $\mathrm{PC}$, it needs photos with oblique rays or closeup photos to include such information to the $3 \mathrm{D}$ modeling to depict brush strokes or the painting habits. 


\subsection{Virtual Reconstruction Based on Similar Examples of the Same Painter/Workshop}

The other method of virtual restoration is virtual reconstruction, which fills the large lost part of the wall-painting. Using the orthophoto made from the 3D-modeling, we sampled the Crucifixion of Merymana Kilisesi (Figure 6). The Crucifixion of here lost the image of St. Mary except for her right hand and the small part of her robe because of a crack formed in the wall which allowed water to penetrate and damage the painting

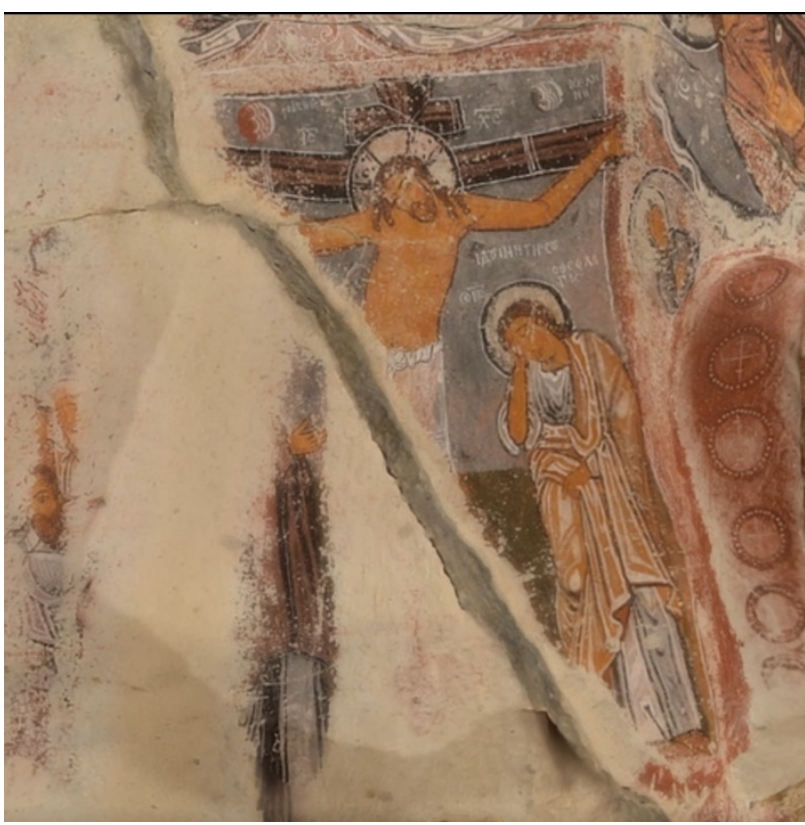

Figure 6. The Crucifixion of Merymana Kilisesi (current image)

The procedure of Virtual Reconstruction is the following:

1) Choose the image of transfer: there are two churches called Sarnıç Kilisesi and Karabulut Kilisesi in Zemi Valley within walking distance from the Open-Air Museum. Thierry (1996) pointed out the same painter (or workshop) painted these three churches based on the styles. While Karabulut Kilisesi lost the Crucifixion, Sarnıç Kilisesi's depiction remains, whose St. Mary (left) keeps almost the original form through the icon of St. John the Theologian (right) is heavily damaged.

2) Make orthophoto of the Crucifixion of Sarnıç Kilisesi (Figure 7) and Conduct the virtual toning to the icon of St. Mary in Sarnıç Kilisesi (Figure 8).

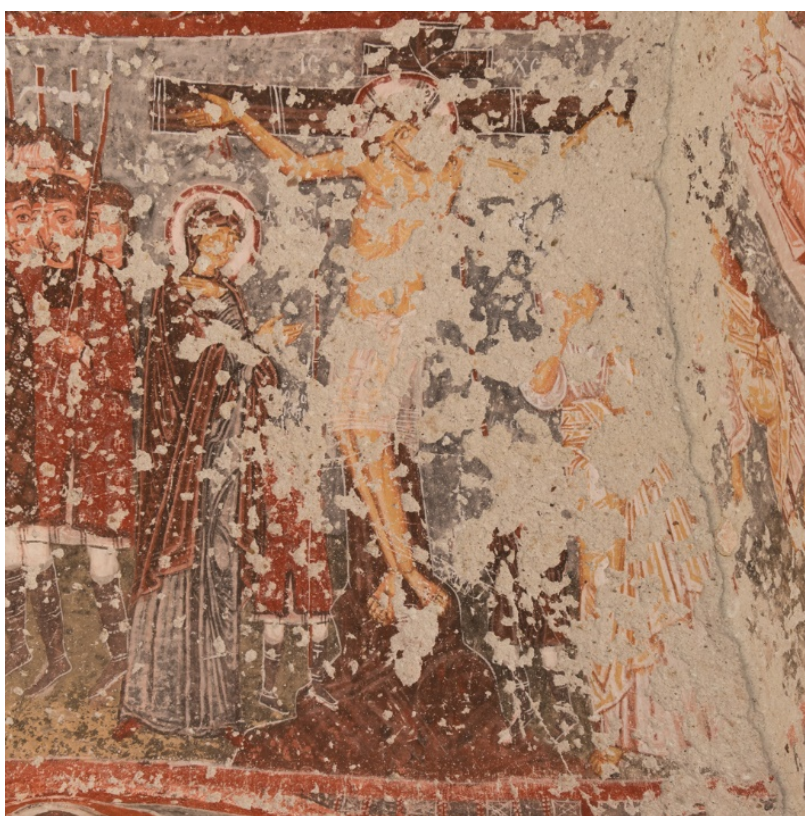

Figure 7. The Crucifixion of Sarnıç Kilisesi (current image)

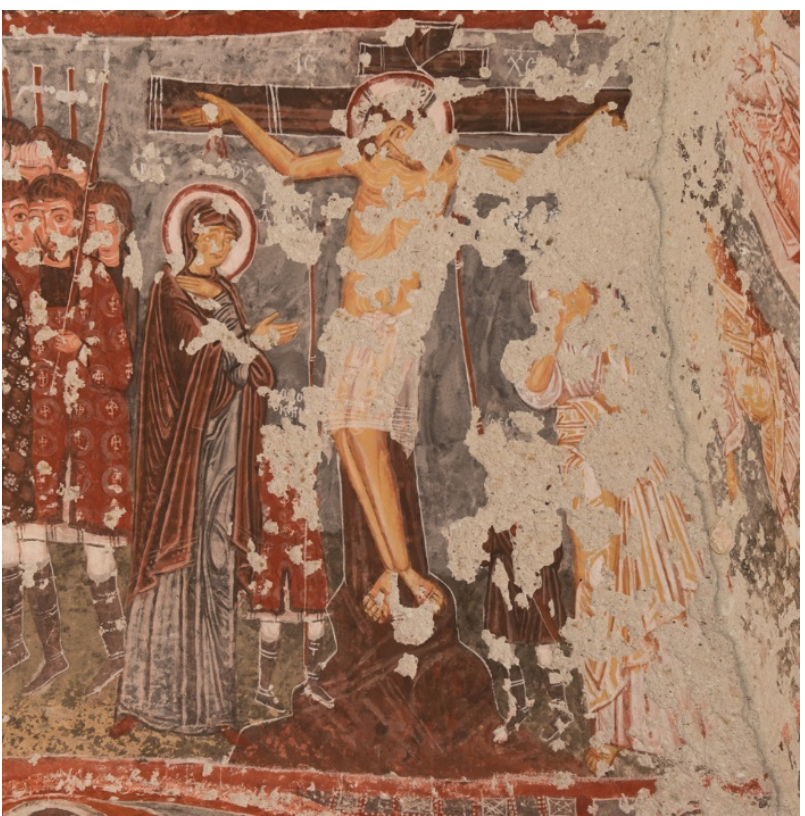

Figure 8. The Crucifixion of Sarnıç Kilisesi (after Virtual Toning)

3) Transfer the part of the icon of St. Mary in Sarnıç Kilisesi (Figure 9) into the Crucifixion in Merymana Kilisesi and Modify the size and color of the icon (Figure 10). 


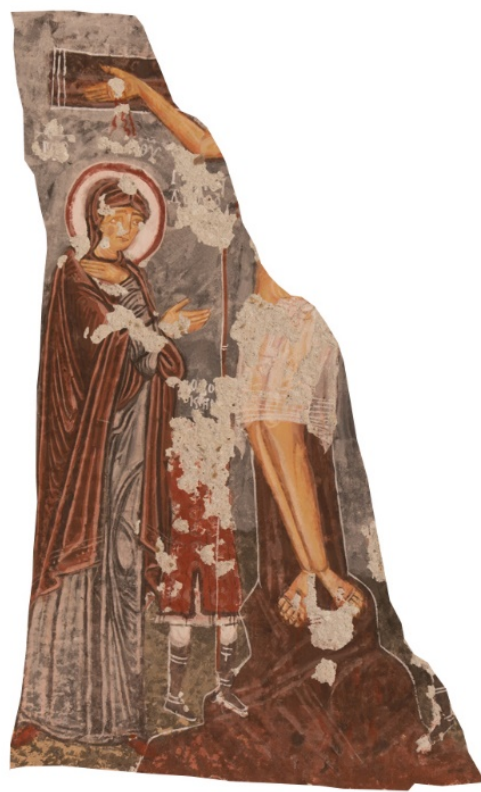

Figure 9. The Virtual toning applied icon of St. Mary in Sarnıç Kilisesi in order to transfer into the Crucifixion of Merymana Kilisesi.

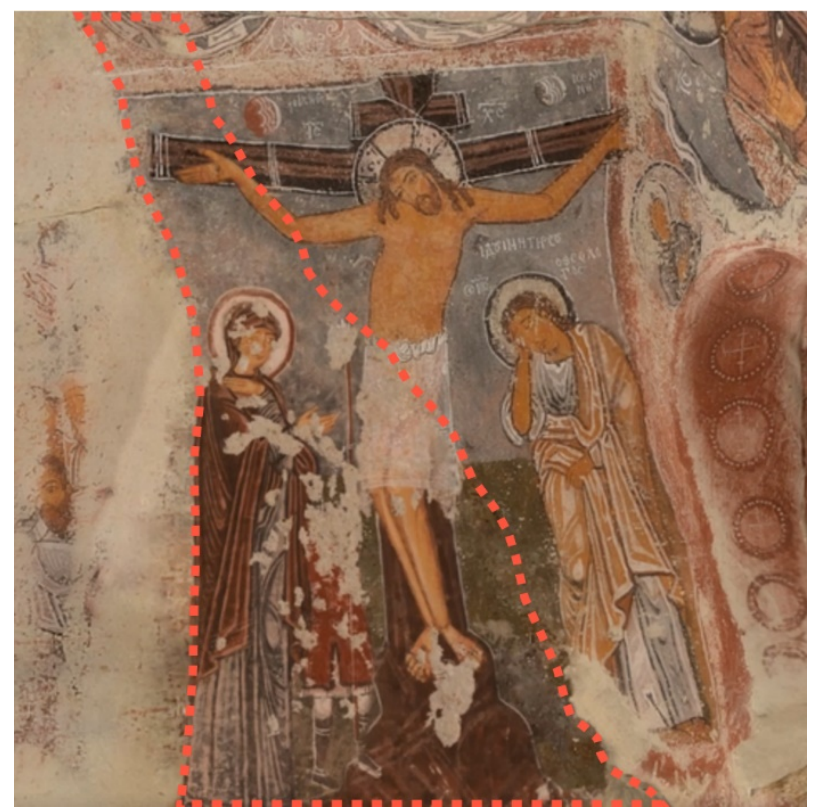

Figure 10. The Crucifixion of Merymana Kilisesi after Virtual Reconstruction (The red dotted line area is the part where virtual reconstruction applied)

Whilst there is a Roman warrior with a spear in front of St. Mary in the reconstructed image, there may be no warrior icon in the original of Merymana Kilisesi as there is no warrior in front of St. John the Theologian of the Crucifixion of Merymana Kilisesi. Therefore, the warrior must be erased.

Such Virtual Reconstruction is also available to other churches in Göreme Valley. For instance, three churches in the Open-Air Museum, called Elmalı Kilise, Çarklı Kilise and Karanlık Kilise built during the midst of 11th century, are so-called 'the Column Churches' because the style of paintings of the three is similar in addition to having a similar cross-in-square plan (Epistein 198081). For instance, the iconography of Crucifixions of the three are close resemblances (Figure 11); i.e. the physiognomy, the drapery and the depictions of muscles in the berry or arms are similar. The iconography of Baptism is as well; the physiognomy, the drapery, the composition, St. John the Baptist is left side of the River and angels are right side of the River, and the depictions of Jordan River, applying white grid to depict streamflow while the Baptism of Carkl Kilise lost a major part of it due to a physical damage (Figure 12-a) and the Baptism of the other two churches (Figure 12-b-c) are preserved almost perfect composition. Therefore, we believe to be able to reconstruct the Baptism of Çarkl1 Kilise virtually by transferring the images from the Baptism of the other two churches and subsequently editing the final result.

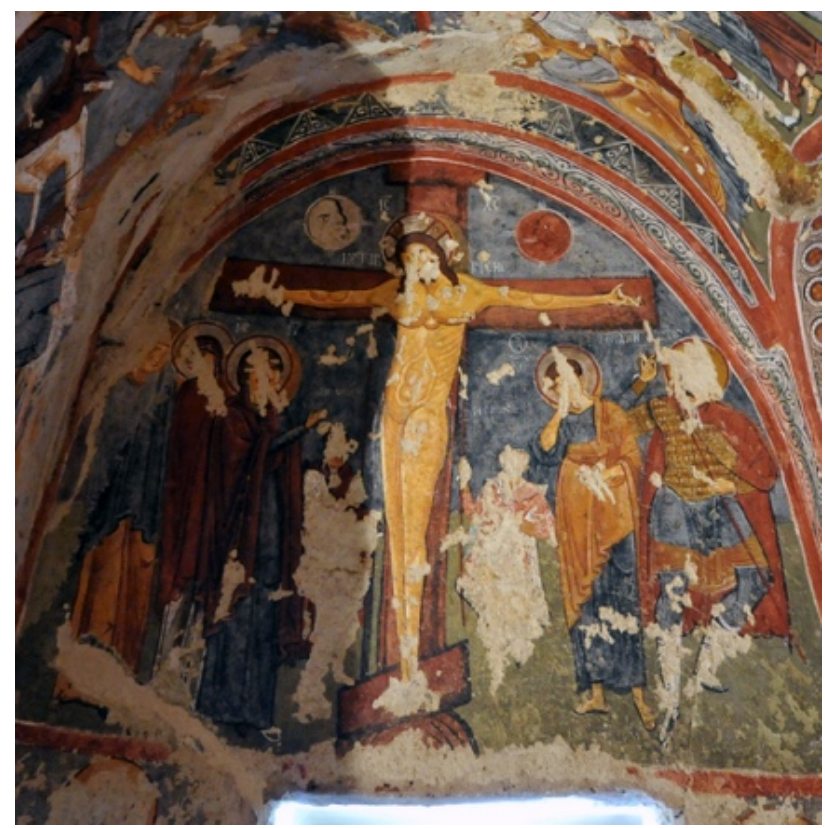

a. Çarklı Kilise

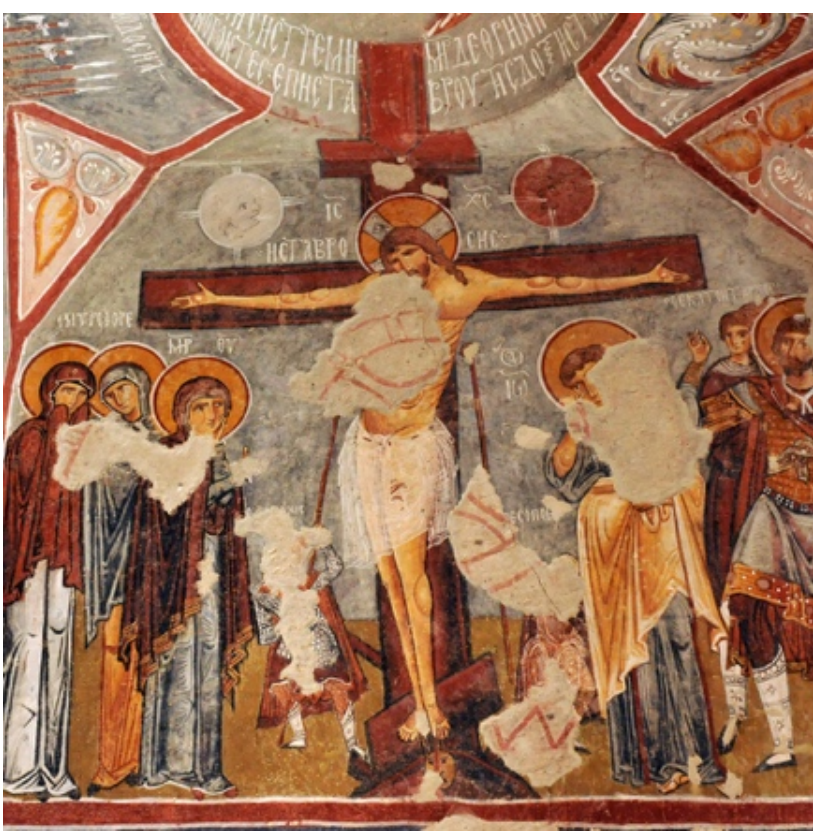

b. Elmalı Kilise 


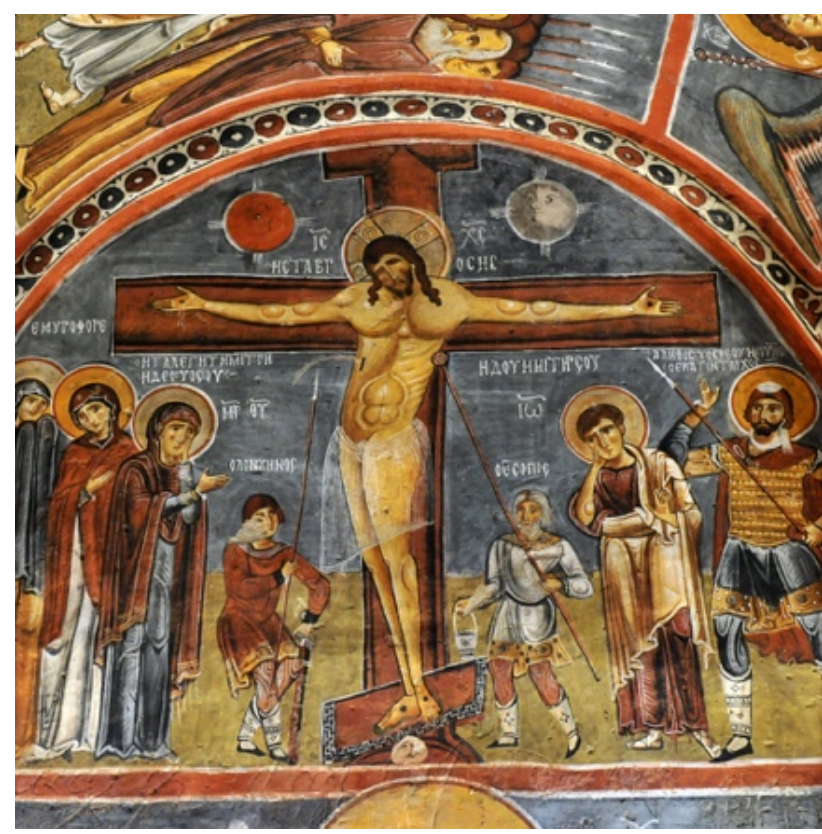

c. Karanlık Kilise

Figure 11. The Comparison of the current images of Crucifixion of 'Column Churches'

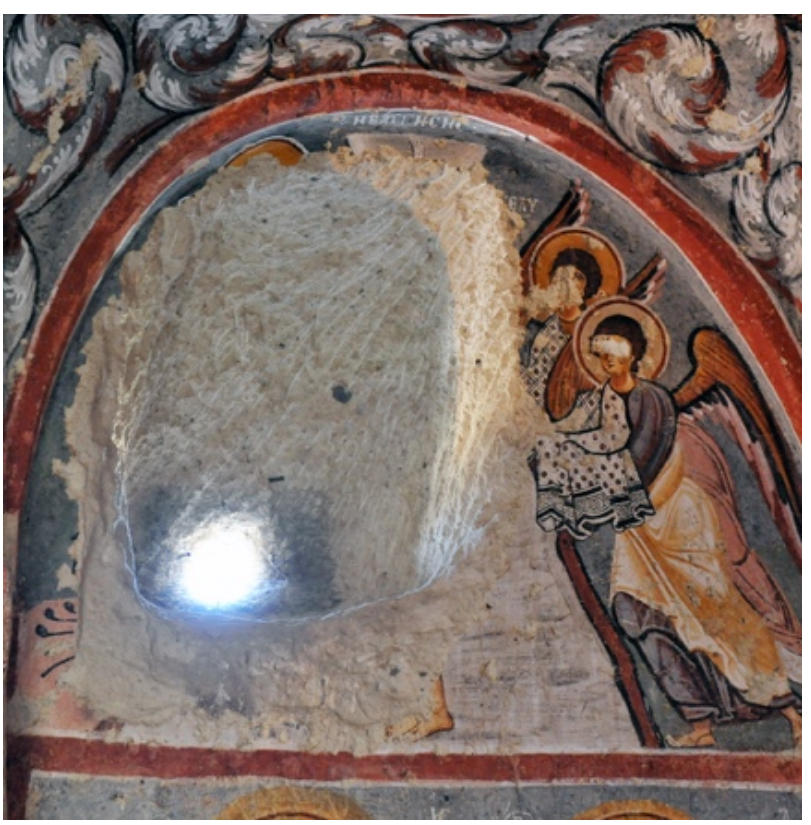

a. Çarklı Kilise

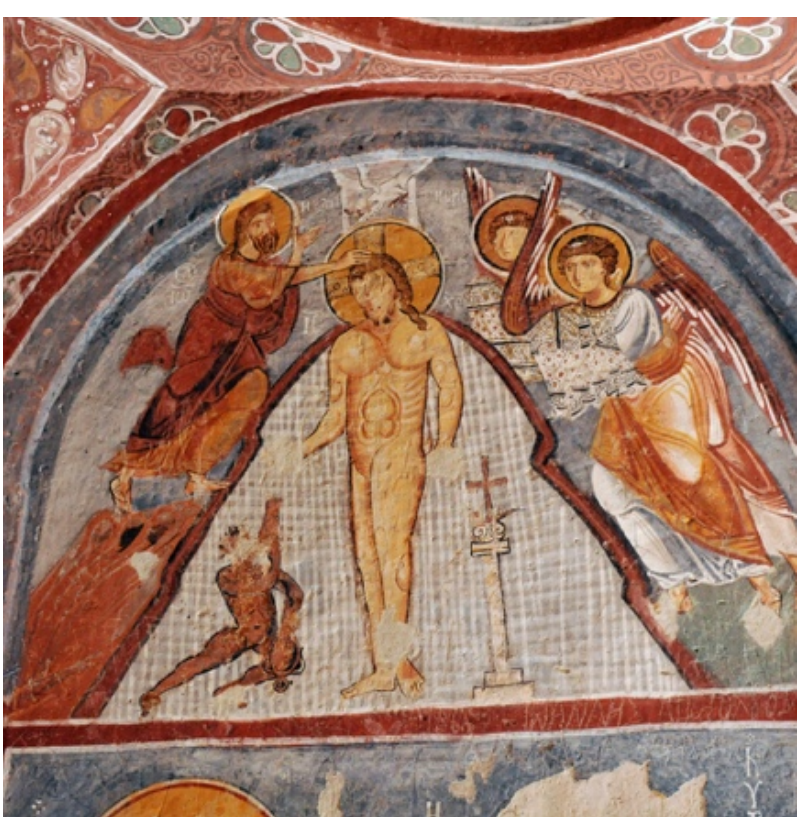

b. Elmalı Kilise

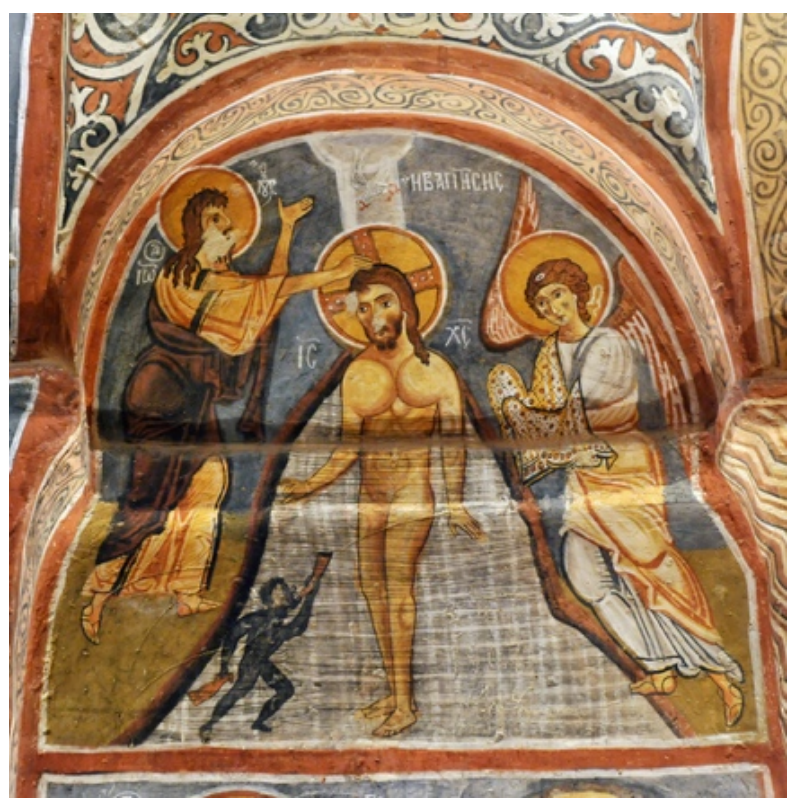

c. Karanlık Kilise

Figure 12. The Comparision of the current images of the Baptism of 'Column Churches'

As we stated above, the special context in Göreme Valley enables us to reconstruct the lost part of the images of wall paintings virtually transferring the images from the other churches using existing technology. We will discuss the availability of the virtual restoration in Göreme Valley and the significance to show such restoration as museum contents in the next chapter.

\section{SOME REMARKS ON THE MUSEUM FOR FUTURE PROGRAM}

Cappadocian rock-hewn churches and these wall-paintings preservations are undermined due to the increase of visitors in addition to its volatile tuff rock environment. While the best way is to restore each church extensively and to protect them, restoration of this scale demands a large budget, time and labor. Although the Göreme Open-Air Museum set admission limits to 
the churches, some of them remain closed to the public like Karanlık Kilise and others can be entered within two minutes, there is no plan to start the restoration. Therefore, the contents which the museum can provide is decreasing.

Advantages of 3D-modeling of rock-hewn churches for Göreme Open-Air Museum are: 1) That they are cheaper and easier to fill museum exhibitions compared to full-scale restoration; 2) it allows the collection of detailed information about the churches without causing further damage; 3 ) easier acquisition of points of discussion, or planning, for future restoration as the 3D-models provide precise and accurate three-dimensional information; 4) easy to use reference for periodical maintenance.

Table 13. The list of the nineteen churches with wall-painting and the similar examples of its wall-paintings in Göreme Valley (The number follows Jerphanion (1925-1942))

\begin{tabular}{|l|l|l|l|l|}
\hline Place & No & Name & $\begin{array}{l}\text { Church by the Same } \\
\text { Painter/Workshop }\end{array}$ & $\begin{array}{l}\text { In/out-side of the } \\
\text { Museum }\end{array}$ \\
\hline Güllü Dere & 4 & Ayvalı & Old Tokalı & Outside \\
\hline Göreme village & 13 & Sarnıç & Karabulut, Meryemana & Outside \\
\hline Göreme village & 14 & Karabulut & Sarnıç, Meryemana & Outside \\
\hline Göreme & $2 a$ & Sakıı & $\begin{array}{l}\text { Yılanlı, Basil, Barbara, } \\
\text { Aikaterine, Kızlar }\end{array}$ & Outside \\
\hline Göreme & 7 & Old Tokalı & Ayvalı & Inside \\
\hline Göreme & 7 & New Tokalı & & Inside \\
\hline Göreme & 9 & Theotokos & & Outside \\
\hline Göreme & 10 & Agios Daniel & \multicolumn{1}{|c|}{ Outside } \\
\hline Göreme & 11 & Agios Eustathios & \multicolumn{1}{|c|}{ Yılanlı, Basil, } & Inside \\
\hline Göreme & 17 & Kızlar & $\begin{array}{l}\text { Saklı, } \\
\text { Barbara, Aikaterine }\end{array}$ \\
\hline Göreme & 18 & Agios Basileios & $\begin{array}{l}\text { Saklı, Yılanlı, Barbara, } \\
\text { Aikaterine, Kızlar }\end{array}$ & Inside \\
\hline Göreme & 19 & Elmalı & Çarıkı, Karanlık & Inside \\
\hline Göreme & 20 & Agia Barbara & & Inside \\
\hline Göreme & 21 & Agia Ekaterine & $\begin{array}{l}\text { Saklı, Yılanlı, Basil, } \\
\text { Barbara, Kızlar }\end{array}$ & Inside \\
\hline Göreme & 22 & Çarıklı & Elmalı, Karanlık & Inside \\
\hline Göreme & 23 & Karanlık & Elmalı, Çarıklı & Inside \\
\hline Göreme & 28 & Yılanlı & $\begin{array}{l}\text { Saklı, Basil, Barbara, } \\
\text { Aikaterine, Kızlar }\end{array}$ & Inside \\
\hline Göreme & 29 & Kılıçlar & Karabulut, Sarnıç & Outside \\
\hline Göreme & 33 & Meryemana & Katside \\
\hline
\end{tabular}

The most important point for virtual reconstructing is some paintings of the churches in Göreme Valley were created by the same painter/workshop. In addition to the churches we discussed in Chapter 2, Old Tokalı church, next to the Open-Air Museum, and Ayvalı Kilise, in Güllü Dere, were painted during 913-920 by the same painter/workshop (Thierry, 1973). Epstein (1975) and Rodley (1985) surmised six churches in Göreme Valley, five churches, Basileios, Kizlar, Barbara, Ekaterine and Y1lanlı, are in the Open-Air Museum, and one church, Sakl1 Kilise, located outside of the museum, were painted in the latter half of 11 th century by the same painter/workshop; therefore, these churches are called Y1lanlı Group. Thus, thirteen of nineteen churches with paintings under the Open-Air Museum have similar icons by the same painter/workshop (Table 13). The significant ratio of wallpaintings in these churches have similar examples by the same painter/workshop is the most significant advantage of the museum in Göreme, center as a monastic community of Cappadocia historically. No other area in Cappadocia has surviving wall-paintings in such density; i.e. only the Göreme Valley can provide enough materials for virtual restoration. If so, what is a value of $3 \mathrm{D}$-modeling and virtual restoration for the museum?
Although some churches are temporarily closed for maintenance or restoration, visitors can know the information about the church itself, see the progress of the works and understand the reason of closing through the 3D-modeling exhibition. Furthermore, visitors can understand the history of the churches and the work done to the churches to see the changes experienced during the churches lifetime via 3D-modeling. Thus, 3D-modeling can create an engaging exhibit for cultural properties; i.e. 3Dmodeling exhibition may also bring educational effect.

The current trend all over the world is to avoid restoration as it is against the principles for repair, moreover, some argue against the erasing graffiti because those can be interpreted in its own right as part of the history of the monument. Virtual restoration is unrelated to such discussion. One idea is conducting just emergency treatment of the real wall-paintings and showing restored wall-paintings when visitors view the piece through the digital device like a tablet. This idea can decrease the duration and the cost of repair and bring monetary benefits to the exhibition, which can compensate for the cost of necessary repairs. This medium can also show simulations of activities performed in the churches like the rituals by monks/nuns or hewing and making by craftsmen.

The mission of museums is, in our opinion, not only preservation or repair their materials, but also to provide new findings and learning opportunities for visitors. The 3D-modeling by photogrammetry and virtual restoration used can eliminate to a certain degree the dilemma associated with increasing visitor footfall and physical preservation of the environment, which Göreme Open-Air Museum struggled with for a long time. And of course, the use of high quality interactive digital exhibitions can work to make the museum itself more attractive to visitors.

\section{CONCLUSION}

As we stated above, we made the 3D-modeling of the rock-hewn churches in Göreme Valley, Cappadocia using photogrammetry and presented the two distinct methods of virtual restoration for the wall-paintings: virtual toning, assuming the colors of the small lost part based on the composition of the icons and coloring there virtually, and virtual reconstruction, transferring the images of the lost part from the remained images by the same painter/ workshop virtually, the latter is only possible as Göreme Valley's special context. Then we discussed the advantages and possibility of the 3D-modelling exhibition, which can reduce the problems facing the Göreme Open-Air Museum: increasing visitors and deterioration of preservation environment surrounding the churches; and promoting the educational aspect of the museum alongside providing new findings and educational experiences for the visitors to the site.

Thus, we believe 3D-modeling helps to achieve the mission of museums, providing new findings and learning opportunities for visitors in addition to preserving and repairing their materials.

\section{ACKNOWLEDGEMENTS}

This work was supported by Japanese Society for the Promotion of Science Grant-in-Aid for Challenging Research (Exploratory) Number 17K18461.

\section{REFERENCES}

Cariceci, M., Inglese, C., 2014. Laser scanning and Automated Photogrammetry for Knowledge and Representation of the Rupestrian Architecture in Cappadocia: Sahinefendi and the 
Open Air Museum of Goreme. CAA 2014 21st Century Archaeology, Concepts, methods and tools Proceedings of the 42nd Annual Conference on Computer Applications and Quantitative Methods in Archaeology, 87-94.

Colonnese, F., Carpiceci, M., Inglese, C., 2016. Conveying Cappadocia. A new representation model for rock-cave architecture by contour lines and chromatic codes. Virtual Archaeology Review 7(14), 13-19.

Epstein, A. W., 1975. Rock-cut Chapels in Göreme Valley, Cappadocia: The Y1lanl1 Group and the Column Churches. Cahiers archélogiques 24, 115-135.

Epstein, A. W., 1980-81. The Fresco Decoration of the Column Churches, Göreme Valley, Cappadocia: Consideration of Their Chronology and Their Models. Cahiers archélogiques 29, 27-45.

Erguler, Z. A., 2009. Field-based Experimental Determination of the Weathering Rates of the Cappadocian Tuffs. Engineering Geology 105, 186-199.

Jerphanion, G. de, 1925-1942. Une nouvelle province de l'art byzantin: les églises rupestres de Cappadoce, 4 vols., Paris.

Jolivet-Lévy, C., 1991. Les églises byzantines de Cappadoce: le programme iconographique de l'abside et de ses abords. Centre national de la recherchhe scientifique, Paris.

Jolivet-Lévy, C., 2015. La Cappadoce: un siècle après G. de Jerphanion, 2 vols., Geuthner, Paris.

Masuda, T., 2014. Byzantine Seido Soshoku Program Ron [Decoration Program of Byzantine Churches], Chuo Koron Bijutsu Shuppan, Tokyo.

Restle, M., 1969. Byzantine Wall Painting in Asia Minor. 3 vols., New York Graphic Society, Greenwich, CT, USA.

Rodley, L., 1985. Cave Monasteries of Byzantine Cappadocia. Cambridge University Press, New York.

Thierry, N., 1973. Un atelier de peinture du début du Xe siècle en Cappadoce : l'atelier de l'ancienne église de Tokali. Bulletin de la Société nationale des Antiquaires de France 1971, 170-178.

Thierry, N., 1996. Un atelier cappadocien du XIe siècle à MaçanGöreme, Cahiers archélogique 44,117-140. 